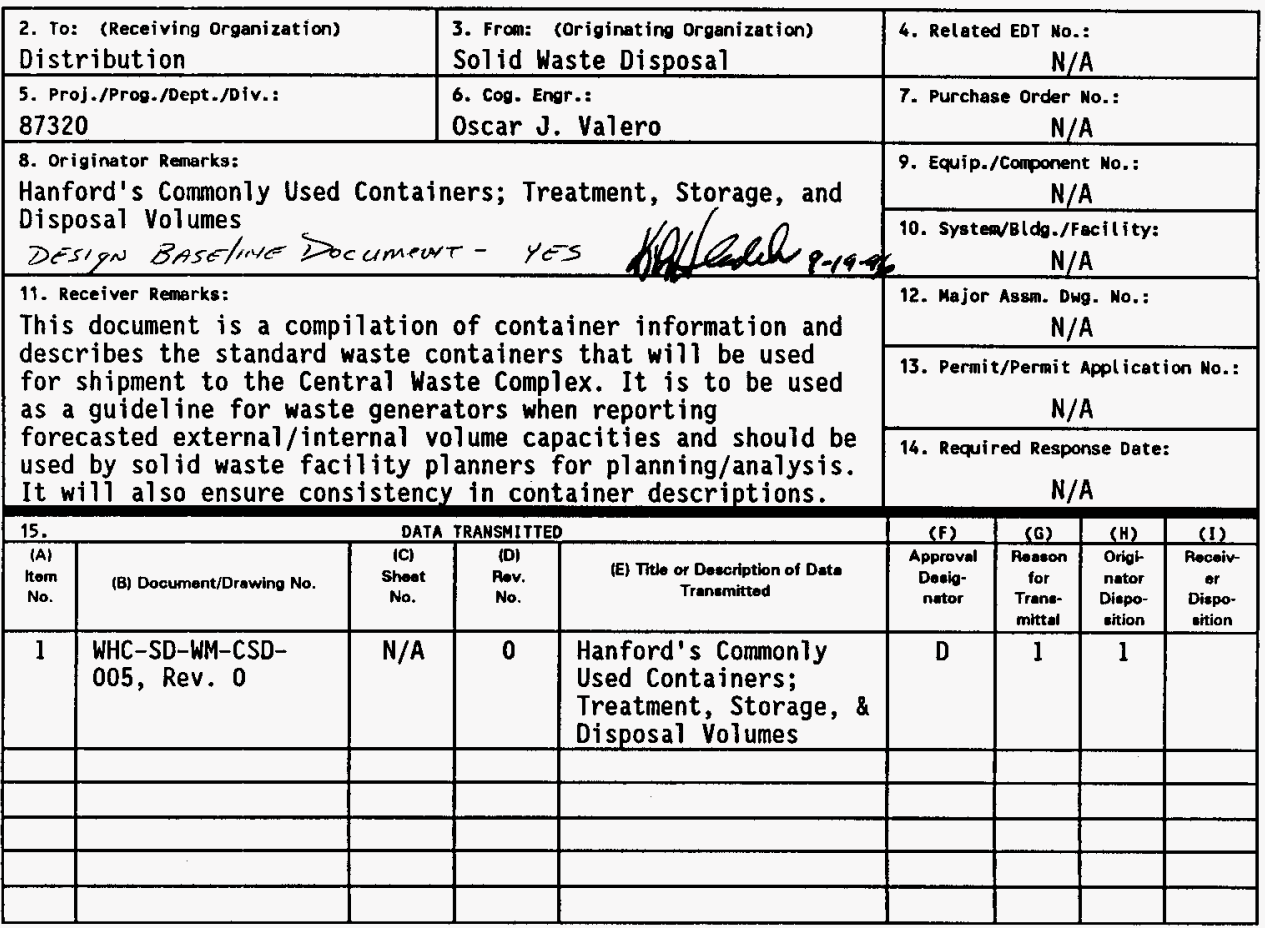

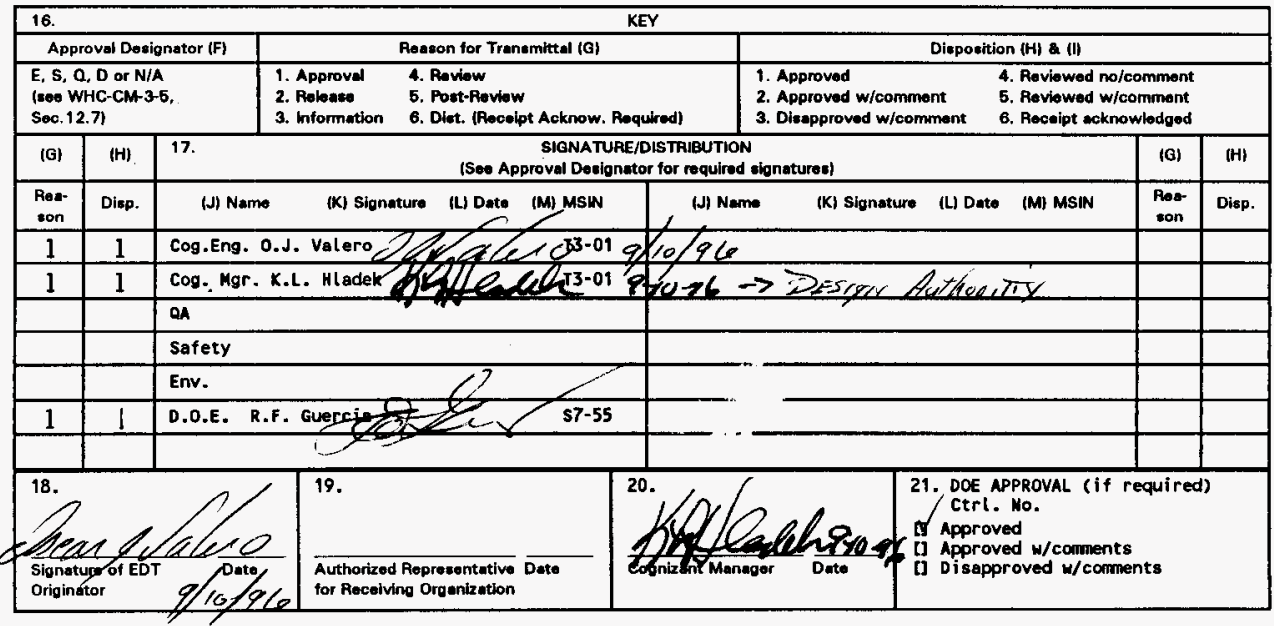




\section{Hanford's Commonly Used Containers; Treatment, Storage, and Disposal Volumes}

\section{Oscar J. Valero}

Westinghouse Hanford, Richland, WA 99352

U.S. Department of Energy Contract DE-AC06-87RL10930
EDT/ECN: $\quad 618512$
Org Code: 87320
UC: 2020
B\&R Code: YNO100000
Charge Code: $E 48355$
Total Pages: 2324 Ene $9 / 10 / 46$

Key Words: Hanford's Commonly Used Containers; Treatment, Storage, and Disposal Volumes.

Abstract: This document is a compilation of container information and describes the standard waste containers that will be used for shipment to the Central Waste Complex. It is to be used as a guideline for waste generators when reporting forecasted external/internal volume capacities and should be used by solid waste facility planners for planning/analysis. It will also ensure consistency in container descriptions.

TRADEMARK DISCLAIMER. Reference herein to any specific commercial product, process, or service by trade name, trademark, manufacturer, or otherwise, does not necessarily constitute or imply its endorsement, recommendation, or favoring by the United States Government or any agency thereof or its contractors or subcontractors.

Printed in the United states of America. To obtain copies of this document, contact: WHC/BCS Document Control Services, P.O. Box 1970, Mailstop H6-08, Richland WA 99352, Phone (509) 372-2420; Fax (509) 376-4989.
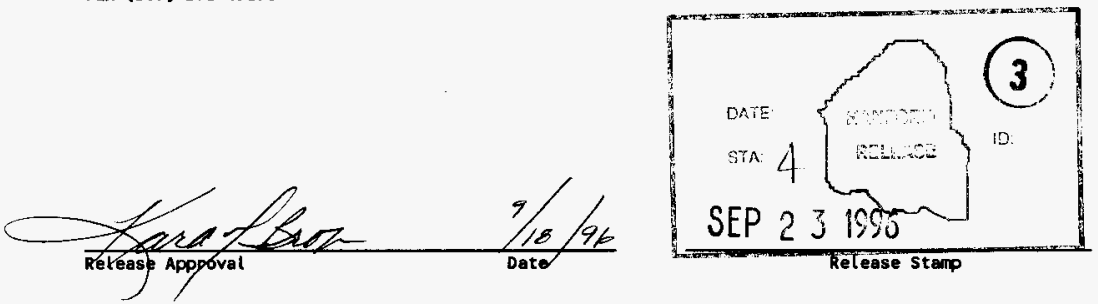

\section{Approved for Public Release}




\section{Hanford's Commonly Used Containers; Treatment, Storage, and Disposal Volumes}

\section{O. J. Valero}

Westinghouse Hanford Company

K. J. Templeton

H. S. Konynenbelt

M. C. Bierschbach

Pacific Northwest National Laboratory

M. R. Carver

ICF Kaiser Hanford Company

Date Published

September 1996

Prepared for the U.S. Department of Energy

Assistant Secretary for Environmental Management

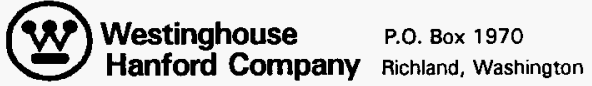

Management and Operations Contractor for the

U.S. Department of Energy under Contract DE-AC06-87RL10930

Approved for public release; distribution is unlimited 


\section{WHC-SD-WM-CSD-005, Rev. 0}

\section{Executive Summary}

The main purpose of this report is to ensure consistency in the use of internal, external, and effective storage volumes of waste containers commonly used for shipment of waste on the Hanford Site. This report provides treatment, storage, and disposal volumes for drums, boxes, long-length equipment containers, and other containers. Footprint areas are also provided.

For accounting purposes, it is convenient to express storage volumes in drum equivalents. The drum equivalent of a container is defined as the number of standard 208-liter drums that would be displaced if that container were stored in a building instead of the standard drums. Drum equivalents range from 0.444 for 30 - and 61-liter drums to 222 for the larger long-length equipment containers.

The containers discussed herein are identified from the Hanford specifications used to procure containers used for the storage or disposal of waste. 
WHC-SD-WM-CSD-005, Rev. 0

Intentionally Left Blank 
WHC-SD-WM-CSD-005, Rev. 0

\section{Contents}

Executive Summary $\ldots \ldots \ldots \ldots \ldots \ldots \ldots \ldots \ldots \ldots \ldots \ldots \ldots \ldots \ldots$ iii

1.0 Introduction $\ldots \ldots \ldots \ldots \ldots \ldots \ldots \ldots \ldots \ldots \ldots \ldots \ldots \ldots$

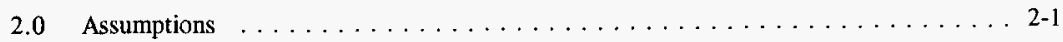

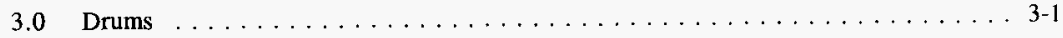

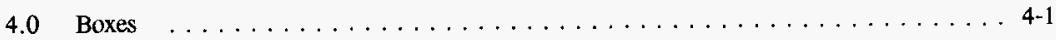

5.0 Long-Length Equipment Containers $\ldots \ldots \ldots \ldots \ldots \ldots \ldots \ldots \ldots \ldots \ldots$

6.0 Other Containers $\ldots \ldots \ldots \ldots \ldots \ldots \ldots \ldots \ldots \ldots \ldots \ldots \ldots$

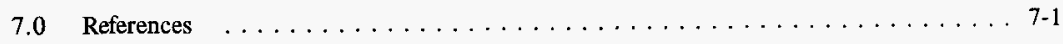


WHC-SD-WM-CSD-005, Rev. 0

Figures

4-1 Example Storage Arrangement for Drums and Boxes $\ldots \ldots \ldots \ldots \ldots \ldots$

\section{Tables}

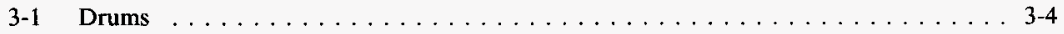

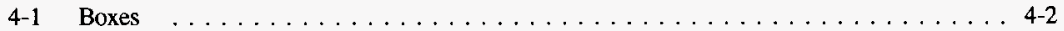

5-1 Long-Length Equipment Containers $\ldots \ldots \ldots \ldots \ldots \ldots \ldots \ldots \ldots$

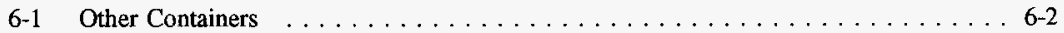


WHC-SD-WM-CSD-005, Rev. 0

\subsection{Introduction}

This report identifies waste containers commonly used for shipment of waste on the Hanford Site and their corresponding volumes for treatment, storage, and disposal, as well as their footprint areas. The containers discussed herein are identified from the Hanford specifications used to procure containers used for the storage or disposal of waste. The main purpose of this report is to ensure consistency in the use of internal and external volumes of waste containers for treatment, storage, and disposal purposes.

The container information addressed in this report was compiled from a variety of sources and is intended to be used as a reference for Westinghouse Hanford Company (WHC) staff and potentially for waste generators. The following sources were used to develop this report: operational personnel at the Central Waste Complex (CWC), ANSI MH2-1991, 1994 Solid Waste Forecast Database, Solid Waste Information Tracking System, HS-V-P-0045, WHC-S-0456, and the Radioactive Hazardous Waste Materials Packaging Directory (WHC-SP-1070).

This report divides containers into drums (Section 3.0), boxes (Section 4.0), long-length equipment containers (Section 5.0), and other containers (Section 6.0). Each section provides a table that details container dimensions and volume. Although numerous types and sizes of containers exist and may be used at Hanford, only those containers considered "most-likely" to be handled at Hanford are included in the tables. Assumptions for each of the table's calculations are provided along with the tables in the following sections.

Unless noted otherwise, all volumes represented in this report are in cubic meters, areas are in square meters, and container dimensions are in meters. The tables list the most commonly used names for the containers.

Drum equivalents are convenient units of measurement. The drum equivalent of a container is defined as the number of standard (1A2) 208-liter drums that would be displaced if that container were stored in a building instead of the standard drums. The drum equivalent of a container is the ratio of the storage volume of the container divided by the storage volume of the standard 208-liter drum. Means for calculating storage volumes and drum equivalents are provided in each section and are included in Tables 3-1 through 6-1. 
WHC-SD-WM-CSD-005, Rev. 0

Intentionally Left Blank 
WHC-SD-WM-CSD-005, Rev. 0

\subsection{Assumptions}

The following assumptions were used to calculate the reported storage, treatment, and disposal volumes as well as to assess the drum equivalents for each container.

- Storage volumes are based on a "reference height," which is the height of a 1A2 208-liter drum plus the height of the pallet on which this drum is placed $(0.886$ meter drum height +0.13 meter pallet height $=1.016$ meters). Thus, even if a container has a different height (for example, the 61-liter drum), this reference height is used to calculate a reference volume.

- In order to assess the number of containers that could be stacked, the midpoint of the highest layer of the specific container is limited so that it does not exceed 10 feet.

- Small drums are either placed on pallets without being stacked or are placed on top of two 208-liter drum tiers.

- Aisle space is 3 feet ( 0.9 meters). This distance is maintained between rows of containers and between any container and a building wall.

- Drums are placed on pallets that are 1.22 meters wide by 1.22 meters long by 0.13 meters high, unless the drum is greater than 208-liters, in which case the drum is placed on a pallet that is 1.63 meters wide by 1.63 meters long by 0.13 meters high.

- Each tier of drums must have a pallet between tiers.

- Drums are stored on pallets that are arranged side-by-side in rows. The rows are one pallet wide with 0.9 meters of aisle space between rows and building walls. The ends of the rows cannot come within 0.9 meters of any wall.

- Boxes and long-length equipment containers are not stored on pallets. They are placed on twoby-fours or directly on the floor of the building.

- Long-length equipment containers cannot be stacked and must have aisle space on all four sides; however, two long-length equipment containers can be placed side-by-side lengthwise.

- For other containers (Table 6-1), if the internal dimensions are unknown, then the external dimensions are used. 
WHC-SD-WM-CSD-005, Rev. 0

Intentionally Left Blank 
WHC-SD-WM-CSD-005, Rev. 0

\subsection{Drums}

Table 3-1 provides a list of standard and non-standard drums projected to be received or used by the Hanford Site. For each drum, the table identifies the container's

- commonly referenced name and rated volume

- external diameter, height, and volume

- internal diameter, height, and volume

- treatment volume

- storage volume

- disposal volume

- drum equivalent

- storage space footprint area

- source documentation.

The following bullets explain the basis for calculating treatment, storage, disposal, and footprint values.

- Treatment: A drum is designated by the typical or nominal amount of material it holds, not by its actual internal volume. For example, a 208-liter drum typically holds about 208 liters of waste, even though its actual internal volume is 220 liters. The treatment volume is defined to be the nominal volume of a drum. Thus, a 208-liter drum has a treatment volume of 208 liters $\left(0.208 \mathrm{~m}^{3}\right)$, a 416 -liter drum has a treatment volume of $0.416 \mathrm{~m}^{3}$, etc. Exceptions to this rule are lead-and concrete-lined drums, where the actual internal volumes of the containers are used as treatment volumes.

- Storage: The storage volume taken up by a drum is based on the size of the drum and the size of the pallet holding the drum. Drums stored at CWC on a standard or overpack pallet are stacked three pallets high. A $0.9-\mathrm{m}$ (3-ft) aisle space is allowed on two opposing sides of the pallet. All drums except the 61-liter (16-gallon) and the 30-liter (8-gallon) sizes are stored four to a pallet. Pallets are placed in parallel rows of arbitrary length with an aisle space of $0.9 \mathrm{~m}$ separating the rows. This means that four drums are stored in an area measuring (pallet length) by (pallet width + aisle space). For the 61-liter and 30-liter drums, nine drums are stored in an area measuring (pallet length) by (pallet width + aisle space). For each drum size listed below, a description is provided for obtaining the storage volume.

416-liter (110-gallon) and 322-liter (85-gallon) drums are stored on an overpack pallet which measures $1.63 \mathrm{~m} \times 1.63 \mathrm{~m} \times 0.13 \mathrm{~m}$ and accommodates up to four of each of these drums sizes. Based on the assumption that four drums are stored in an area measuring (overpack pallet length) by (overpack pallet width + aisle space), the storage volume of one of these containers is calculated as: 
WHC-SD-WM-CSD-005, Rev. 0

$=1 / 4 \times$ (overpack pallet length) $x$ (overpack pallet width + aisle space)

$x$ (reference height)

$=\quad 1 / 4 \times 1.63 \times(1.63+0.9) \times 1.016=1.047 \mathrm{~m}^{3}$.

208-liter (55-gallon), and 114-liter (30-gallon) drums are stored on a standard pallet which measures $1.22 \mathrm{~m} \mathrm{x} 1.22 \mathrm{~m} \times 0.13 \mathrm{~m}$ and accommodates up to four of each of these drum sizes. Based on the assumption that four drums are stored in an area measuring (pallet length) by (pallet width + aisle space), the storage volume of one of these containers is calculated as:

$=\quad 1 / 4 x$ (pallet length) $x$ (pallet width + aisle space) $x$ (reference height)

$=0.657 \mathrm{~m}^{3}$.

61-liter (16-gallon) and 30-liter (8-gallon) drums are also stored on a standard pallet which can accommodate up to nine of each of these drum sizes. Based on the assumption that nine drums are stored in an area measuring (pallet length) by (pallet width + aisle space), the storage volume of one of these containers is calculated as:

$=1 / 9 \times$ (pallet length) $x$ (pallet width + aisle space) $x$ (reference height)

$=0.292 \mathrm{~m}^{3}$.

- Disposal: The disposal volume is equal to the container's greatest diameter squared times the container's greatest height. This volume results in a rectangular column, which is the space consumed by the container in the burial grounds. Therefore, the disposal volume is calculated as:

$=$ diameter squared $x$ height

- Footprint: The amount of floor space the container takes up is referred to as the footprint. The footprint is calculated in a manner similar to the storage volume, but the height factor is excluded.

416-liter (110-gallon) and 322-liter (85-gallon) drums are stored on an overpack pallet which measures $1.63 \mathrm{~m} \times 1.63 \mathrm{~m} \times 0.13 \mathrm{~m}$ and accommodates up to four of each of these drum sizes. Based on the assumption that four drums are stored in an area measuring (overpack pallet length) by (overpack pallet width + aisle space), the footprint of one of these containers is calculated as:

$=\quad 1 / 4 x$ (overpack pallet length) $x$ (overpack pallet width + aisle space)

$=1.031 \mathrm{~m}^{2}$.

208-liter (55-gallon) and 114-liter (30-gallon) drums are stored on a standard pallet which measures $1.22 \mathrm{~m} \mathrm{x} 1.22 \mathrm{~m} \times 0.13 \mathrm{~m}$ and accommodates up to four of each of these drum sizes. Based on the assumption that four drums are stored in an area measuring (pallet length) by (pallet width + aisle space), the footprint of one of these containers is calculated as: 


$$
\begin{aligned}
& \text { WHC-SD-WM-CSD-005, Rev. 0 } \\
& =\quad 1 / 4 \times \text { (pallet length) } x \text { (pallet width }+ \text { aisle space) } \\
& =\quad 0.647 \mathrm{~m}^{2} .
\end{aligned}
$$

61-liter (16-gallon) and 30-liter (8-gallon) drums are also stored on a standard pallet which can accommodate up to nine of each of these drum sizes. Based on the assumption that nine drums are stored in an area measuring (pallet length) by (pallet width + aisle space), the footprint of one of these containers is calculated as:

$=1 / 9 x$ (pallet length) $x$ (pallet width + aisle space)

$=0.287 \mathrm{~m}^{2}$.

- Drum Equivalents: A drum equivalent is the storage volume of a drum expressed in terms of the number of reference 208-liter drums (1A2) displaced. Drum equivalents are listed in Table 3-1. The discussion below describes how the equivalents for each drum size are calculated. In all calculations, it is assumed that the pallets are loaded as full as possible.

The oversized drums (322-liter and 416-liter) are stored in the same manner as the reference drums. The only difference is in the area of the footprint. The ratio of the footprints gives the drum equivalents:

= (over-size drum footprint)/(neference drum footprint)

$=1.031 / 0.647=1.594$

The 114-liter drum and all 208-liter drums are identical as far as storage volume is concerned. Thus their drum equivalents are exactly 1 .

The small drums (61-liter and 30-liter) are stored 9 drums per pallet instead of 4 drums per pallet for the reference drums. If the small drums are placed on top of two 208-liter drum tiers, then nine of these drums displace four standard drums, giving a drum equivalent of $4 / 9=0.44$. On the other hand, if the small drums are not stacked, then the nine small drums displace 12 standard drums, giving a drum equivalent of $12 / 9=1.33$. 
Table 3-1. Drums

\begin{tabular}{|c|c|c|c|c|c|c|c|c|c|c|c|c|}
\hline \multirow{3}{*}{$\begin{array}{c}\text { Nons ond B } \\
\text { Volumed }\end{array}$} & \multicolumn{3}{|c|}{ Brtonis } & \multicolumn{3}{|c|}{ Inemel } & \multirow{3}{*}{ 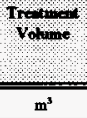 } & \multirow{3}{*}{$\begin{array}{c}\text { solpe } \\
\text { Vowme } \\
\mathrm{m}^{3}\end{array}$} & \multirow{3}{*}{$\begin{array}{l}\text { Droms } \\
\text { Bqurofints }\end{array}$} & \multirow{3}{*}{$\frac{D_{\text {Oolune }}}{\mathrm{m}^{3}}$} & \multirow{3}{*}{$\frac{\mathrm{s}_{\mathrm{orp}}}{\mathrm{s}_{\mathrm{p}}}$} & \multirow[t]{3}{*}{ Retence } \\
\hline & \multicolumn{2}{|c|}{ 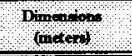 } & \multirow{2}{*}{$\frac{\mathrm{m}^{\mathrm{s}}}{\mathrm{Vol}}$} & \multicolumn{2}{|c|}{ 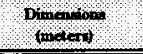 } & \multirow{2}{*}{$\frac{m}{\text { mol }}$} & & & & & & \\
\hline & dia & height & & dia & height & & & & & & & \\
\hline 30 liter $1 \mathrm{~A} 2$ & 0.378 & 0.378 & 0.042 & 0.354 & 0.365 & 0.036 & $\begin{array}{r}6.030 \\
(8 \mathrm{gal})\end{array}$ & 0.292 & See Notes & 0.054 & 0.287 & ANSI MH2 \\
\hline 61 liter $1 A 2$ & 0.378 & 0.683 & 0.077 & 0.354 & 0.643 & 0.063 & $\begin{array}{c}0.061 \\
(16 \mathrm{gal})\end{array}$ & 0.292 & See Notes & 0.098 & 0.287 & - \\
\hline 114 liner $1 \mathrm{~A} 1$ & 0.487 & 0.733 & 0.137 & 0.464 & 0.714 & 0.121 & $\begin{array}{c}0.114 \\
(30 \mathrm{gal})\end{array}$ & 0.657 & 1 & 0.174 & 0.647 & $\cdot$ \\
\hline 114 liter $1 \mathrm{~A} 2$ & 0.500 & 0.740 & 0.145 & 0.464 & 0.711 & 0.120 & $\begin{array}{c}0.114 \\
(30 \mathrm{gal})\end{array}$ & 0.657 & 1 & 0.185 & 0.647 & - \\
\hline 208 liter $1 \mathrm{~A} 1$ & 0.595 & 0.873 & 0.242 & 0.572 & 0.858 & 0.220 & $\begin{array}{l}0.208 \\
\text { (55 gall) }\end{array}$ & 0.657 & 1 & 0.309 & 0.647 & - \\
\hline 208 liter $1 \mathrm{~A} 2$ & 0.608 & 0.886 & 0.257 & 0.572 & 0.855 & 0.220 & $\begin{array}{c}0.208 \\
(55 \mathrm{~g} \leq \mathrm{I})\end{array}$ & 0.657 & 1 & 0.328 & 0.647 & - \\
\hline 322 liter $1 \mathrm{A2}$ & 0.701 & 0.991 & 0.382 & 0.660 & 0.962 & 0.329 & $\begin{array}{c}0.322 \\
(85 \mathrm{gal})\end{array}$ & 1.047 & 1.594 & 0.487 & 1.031 & HS-V-P-0045 \\
\hline 416 liter $1 \mathrm{~A} 2$ & 0.807 & 1.080 & 0.552 & 0.760 & 1.040 & 0.472 & $\begin{array}{c}0.416 \\
(110 \mathrm{gal})\end{array}$ & 1.047 & 1.594 & 0.703 & 1.031 & Vendor Dats \\
\hline 208 liter lesd-lined & 0.608 & 0.886 & 0.257 & 0.243 & 0.457 & 0.021 & $\begin{array}{c}0.021 \\
(5.55 \mathrm{gal})\end{array}$ & 0.657 & 1 & 0.328 & 0.647 & $\mathrm{H}-3-52300$ \\
\hline $\begin{array}{l}208 \text { liter con- } \\
\text { crete lined }\end{array}$ & 0.608 & 0.886 & 0.257 & 0.293 & 0.857 & 0.058 & $\begin{array}{c}0.058 \\
(15.3 \mathrm{gal}) \\
\end{array}$ & 0.657 & 1 & 0.328 & 0.647 & H-3-94445 \\
\hline \multicolumn{3}{|c|}{ Overpull palla $\%$ dht \& larth $=$} & 1.63 & & & & & & & & & \\
\hline \multicolumn{3}{|c|}{ Sundand wiler with \& bogth = } & 1.22 & & & & & & & & & \\
\hline \multicolumn{3}{|l|}{ Pallet beight $=$} & 0.13 & & & & & & & & & \\
\hline \multicolumn{3}{|l|}{ Aiske width = } & 0.90 & & & & & & & & & \\
\hline
\end{tabular}

- External volumes are calculated using the greatest lengths of any dimension and an equation that follows the periphery of the container. lnternal volumes are calculated from space that may be occupied by waste. This includes or neglects when reasonable the space occupied by supporting members (e.g., the hoops in a drum).

- For 30- and 61-liter drums, the drum equivalent is 4/9 (0.444), if drums arc stacked on top of two 208-liter tiers. If not stacked, drum equivalent is $12 / 9(1.333)$.

- Values for volumes and areas may not match values calculated from dimensions due to rounding. 


\subsection{Boxes}

Table 4-1 provides a list of standard and non-standard boxes projected to be received or used by the Hanford Site. For each box, the table identifies the container's length; width; height; internal and external volumes; treatment, storage, and disposal volumes; and footprint area. The following bullets explain the basis for calculating treatment, storage, disposal, and footprint values.

- Treatment: The treatment volume is equal to the internal volume of the container minus two inches $(0.05 \mathrm{~m})$ of "headspace." For example, if the internal dimensions of a box are $0.60 \mathrm{~m}$ high, $1.20 \mathrm{~m}$ wide, and $2.40 \mathrm{~m}$ deep, its treatment volume is $(0.60-0.05) \times 1.2 \times 2.4=1.58$ $\mathrm{m}^{3}$. There is limited information on the internal volumes of the boxes. Currently there is no process at Hanford that dictates what manufacturer can be used in the purchase of these containers and there is also no process at Hanford that forces the generators to refrain from purchasing their own containers from the manufacturer of their choice. The external dimensions for containers with an asterisk following their names are calculated from the internal dimensions. The calculations are based on the assumed efficiency defined in the bottom of the table.

- Storage: The storage volume of each commonly used box is based on its external volume (plus an allowance for aisle space) and the number of boxes to be stacked. Boxes are placed side-byside lengthwise until they are 0.9 meters from the wall of the building. It is assumed that only boxes of equal dimensions are stacked. The volume consumed when storing boxes can be expressed by the following equation:

$=$ (external box length + aisle space) $x$ (external box width) $x 3 /($ number of boxes to be stacked) $x$ (reference height)

- Drum Equivalents: Table 4-1 also gives the storage volume of Hanford boxes expressed in drum equivalents. This is determined by dividing the storage volume of the box by the storage volume of the standard 208-liter drum (208 liter 1A2):

$=$ (container storage volume) $/(0.657)$

Figure 4-1 shows a possible storage arrangement of boxes and drums.

- Disposal: The disposal volume is equal to the external volume of the box.

- Footprint: The footprint is assumed to be equal to the area of the box, including an allowance for aisle space between rows.

$=$ (external box length + aisle space) $x$ (external box width) 
Table 4-1. Boxes

\begin{tabular}{|c|c|c|c|c|c|c|c|c|c|c|c|c|c|c|c|}
\hline \multirow[t]{3}{*}{ Conmon None } & \multirow{3}{*}{ 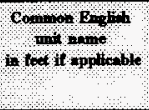 } & \multicolumn{4}{|c|}{ Nornd } & \multicolumn{4}{|c|}{ Internil } & \multirow{3}{*}{$\frac{T_{\text {Totume }}}{m^{\prime}}$} & \multirow{3}{*}{ 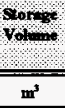 } & \multirow{3}{*}{ Bownolots } & \multirow{3}{*}{ 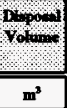 } & \multirow{3}{*}{ 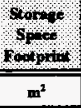 } & \multirow{3}{*}{ 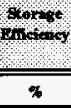 } \\
\hline & & \multicolumn{3}{|c|}{ 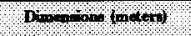 } & \multirow{2}{*}{$\frac{\mathbf{m}^{2}}{\text { Vod }}$} & \multicolumn{3}{|c|}{ 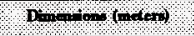 } & \multirow{2}{*}{$\frac{\mathrm{m}^{\prime}}{\mathrm{Vol}}$} & & & & & & \\
\hline & & height & width & length & & height & widkh & length & & & & & & & \\
\hline MB-1* & $2 \times 2 \times 6$ & 0.67 & 0.61 & 1.82 & 0.74 & 0.60 & 0.60 & 1.80 & 0.65 & 0.59 & t. 69 & 2.57 & 0.74 & 1.66 & 26 \\
\hline MB-П" & $3 \times 3 \times 6$ & 1.00 & 0.92 & 1.82 & 1.67 & 0.90 & 0.90 & 1.80 & 1.46 & 1.38 & 2.54 & 3.87 & 1.67 & 2.50 & 32 \\
\hline MB-II" & $2 \times 4 \times 8$ & 0.67 & 1.22 & 1.82 & 1.48 & 0.60 & 1.20 & 2.40 & 1.73 & 1.58 & 3.37 & 5.13 & 1.48 & 3.32 & 49 \\
\hline MB-IV* & $3.3 \times 4.3 \times 6.3$ & 1.11 & 1.32 & 1.95 & 2.87 & 1.00 & 1.30 & 1.93 & 2.51 & 2.38 & 3.82 & 5.82 & 2.87 & 3.76 & 32 \\
\hline $\mathrm{MB}-\mathrm{V}=$ & $4 \times 4 \times 8$ & 1.33 & 1.22 & 2.43 & 3.95 & 1.20 & 1.20 & 2.40 & 3.46 & 3.31 & 4.13 & 6.28 & 3.95 & 4.06 & 40 \\
\hline MB-VI* & $5 \times 5 \times 9$ & 1.67 & 1.53 & 2.83 & 7.20 & 1.50 & 1.50 & 2.80 & 6.30 & 6.09 & 8.70 & 13.24 & 7.20 & 5.71 & 38 \\
\hline H-2-42701 & $4 \times 4 \times 8$ & 1.36 & 1.22 & 2.44 & 4.05 & 1.14 & 1.00 & 2.32 & 3.29 & 2.53 & 4.14 & 6.30 & 4.05 & 4.07 & 38 \\
\hline $\mathrm{CFC}^{\prime} \cdot \mathrm{B}-25$ & $4 \times 4 \times 6$ & 1.32 & 1.19 & 1.85 & 2.92 & 1.19 & 1.17 & 1.83 & 2.55 & 2.44 & 3.32 & 5.06 & 2.92 & 3.27 & 36 \\
\hline SWB & & 0.94 & 1.38 & 1.80 & 2.09 & 0.87 & 1.32 & 1.14 & 1.80 & 1.23 & 3.79 & 5.76 & 2.09 & 3.73 & 32 \\
\hline Sea Land* & $4 \times 8 \times 20$ & 1.20 & 2.50 & 6.10 & 18.30 & 1.08 & 2.46 & 6.03 & 16.01 & 15.28 & 26.67 & 40.59 & 18.30 & 17.50 & 55 \\
\hline & & & & & & Height & rincy & & 0.900 & & & & & & \\
\hline & & & & & & Longth $\mathrm{E}$ & icietsy & & 0.989 & & & & & & \\
\hline & & Xinle wi & & & 0.90 & Heighte & ord & & 3.660 & & & & & & \\
\hline
\end{tabular}

- External volumes are calculated using the greatest lengths of any dimension and an equation that follows the periphery of the container.

- Internal volumes are calculated from space that may be occupied by waste. This includes or neglects when reasonable the space occupied by supporting members (e.g., the hoops in a drum).

- Containers with an asterisk are not design specific. Therefore, both interior and exterior dimensions are not known. The unknown dimensions are calculated using the efficiencies assumed in the table.

- The MB containers originate from the specification WHC-S-0456, Rev. 0.

- MB-VI and the "Sea Land" are assumed to be stacked two-high based on weight limits. Remaining boxes are assumed to be stacked three-high.

- Values for volumes, drum equivalents, and areas may not match values calculated from dimensions due to rounding. 


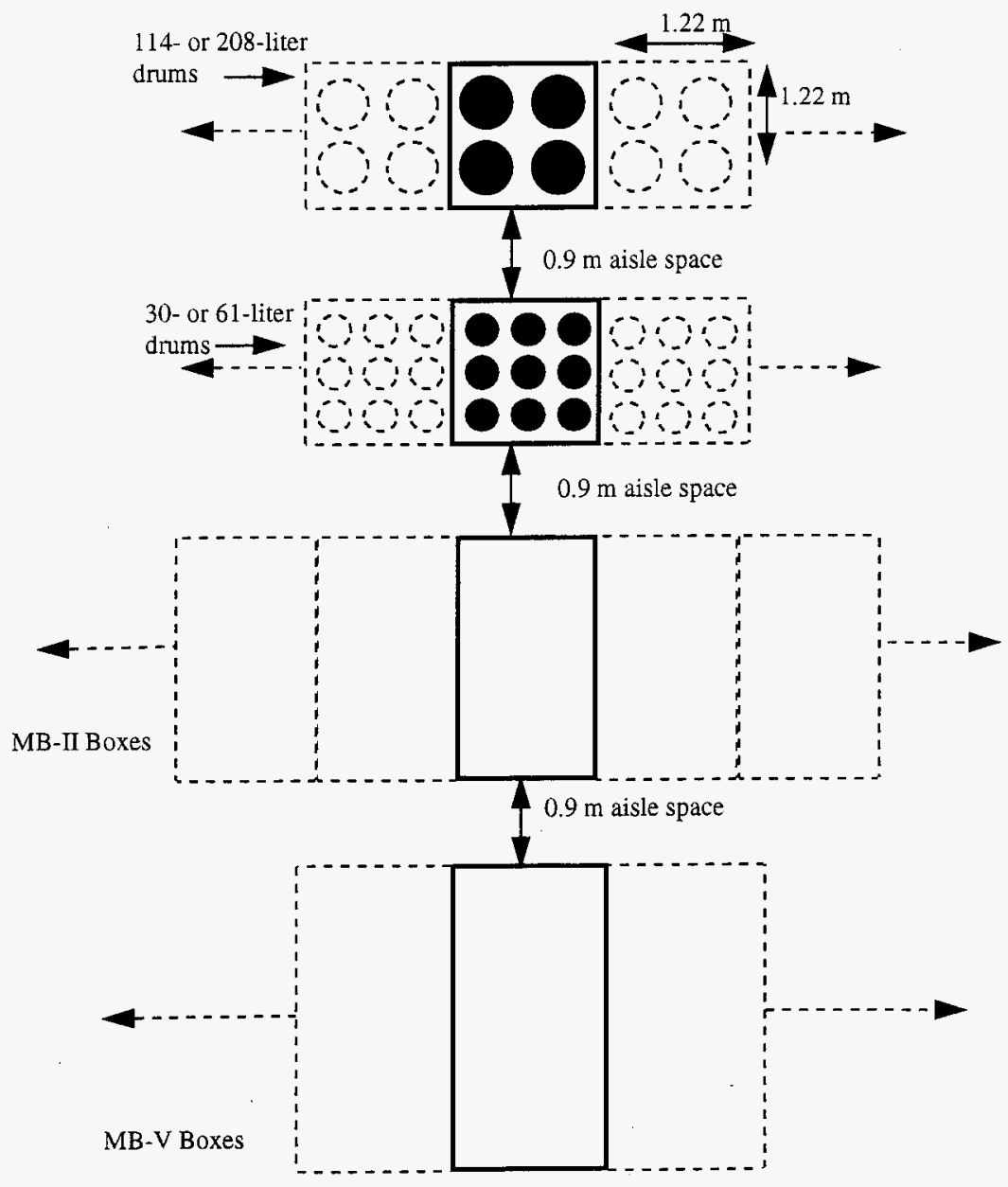

Figure 4.1. Examole Storage Arrangement for Drums and Boxes 
WHC-SD-WM-CSD-005, Rev. 0

Intentionally Left Blank 
WHC-SD-WM-CSD-005, Rev. 0

\subsection{Long-Length Equipment Containers}

Table 5-1 provides a list of standard long-length equipment containers, or LECs, projected to be received or used by the Hanford Site. For each LEC, the table identifies the container's length; width; height; internal and external volumes; treatment, storage (in $\mathrm{m}^{3}$ and drum equivalents), and disposal volumes; and footprint area. Due to the uncertainty in the development and programmatic changes of the LECs, the descriptions and dimensions of the LEC may change. The following bullets explain the basis for calculating treatment, storage, disposal, and footprint values.

- Treatment: The treatment volume for LECs is based on the external dimensions of the container and subtracting $0.10 \mathrm{~m}$, assumed to be the thickness of the metal, from the sides and ends.

- Storage: The LECs are special containers fabricated for use in retrieval operations of long-length equipment from the single-shell and double-shell tanks. Currently there are nine LECs identified as containers to be used for disposal of the long-length equipment. It is assumed that these LECs will be shipped to CWC for interim storage. This container is not stacked, but it is assumed that similar containers will be grouped in units of two such that their long dimensions are parallel to each other with no space between them and with $0.9 \mathrm{~m}$ of aisle space on all four sides of a group. The storage volume is therefore calculated as:

$=\quad 1 / 2 \times$ (container length + aisle space $) \times(2 \times$ container width + aisle space $) \times 3$ $x$ (reference height)

- Drum Equivalents: Table 5-I also gives the storage volume of LECs in drum equivalents, which is simply the storage volume of the container divided by the storage volume of the standard 208liter drum (208 liter 1A2):

$=$ (containér storage volume) / (0.657)

- Disposal: The disposal volume is equal to the external volume of the container.

- Footprint: The footprint is calculated as:

$=\quad 1 / 2 x$ (container length + aisle space $) \times(2 x$ container width + aisle space $)$ 
Table 5-1. Long Length Equipment Containers

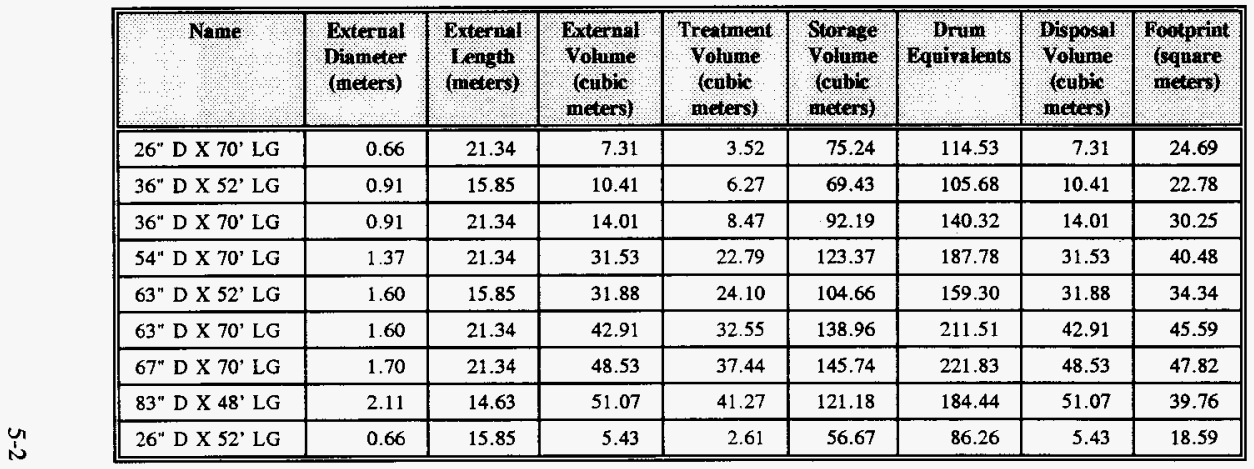

NOTE: Values for volumes and areas may not match values calculated from dimensions due to rounding. 


\subsection{Other Containers}

Table 6-1 provides a list of containers other than drums, LECs, or boxes that are projected to be received or used by the Hanford Site. For each container, the table identifies the container's dimensions; internal and external volumes; treatment, storage, and disposal volumes; and footprint area. The following bullets explain the basis for calculating treatment, storage, disposal and footprint values.

- Treatment: The treatment volume is equal to the internal volume of the container.

- Storage: It is assumed that the containers will be placed on rectangles of pallets (either $1.22-\mathrm{m}$ pallets or $1.63-\mathrm{m}$ pallets, depending on the dimensions of the container). The containers are placed on the smallest number of pallets as possible. (For example, the ion exchange column measures 0.46 meters in diameter by 1.76 meters long. This object will fit on a rectangle that is 1 pallet wide by 2 pallets long [1.22 $\mathrm{m}$ by $2.44 \mathrm{~m}]$.) It is also assumed that like containers will be placed adjacent to each other to form rows, similar to the arrangement of boxes, with aisle space of $0.9 \mathrm{~m}$ separating each row. Since the containers are not stacked, the effective height of the container is the same as the height of three tiers of standard 208-liter drums. The storage volume is calculated as:

$=$ (total length of pallets + aisle space) $x$ (total width of pallets) $x 3 \times$ (reference height)

- Drum Equivalents: The drum equivalent volume is found simply by dividing the storage volume of the container by the storage volume $(0.657 \mathrm{~m})$ of the standard 208 -liter drum (1 A2).

- Disposal: The disposal volume is also assumed to be equal to the external volume of the container.

- Footprint: The footprint is assumed to be equal to the length of the pallets times the width of the pallets, including an allowance for aisle space on all sides of the rectangle. The footprint is calculated as:

$=$ (total length of pallets + aisle space) $x$ (total width of pallets) 


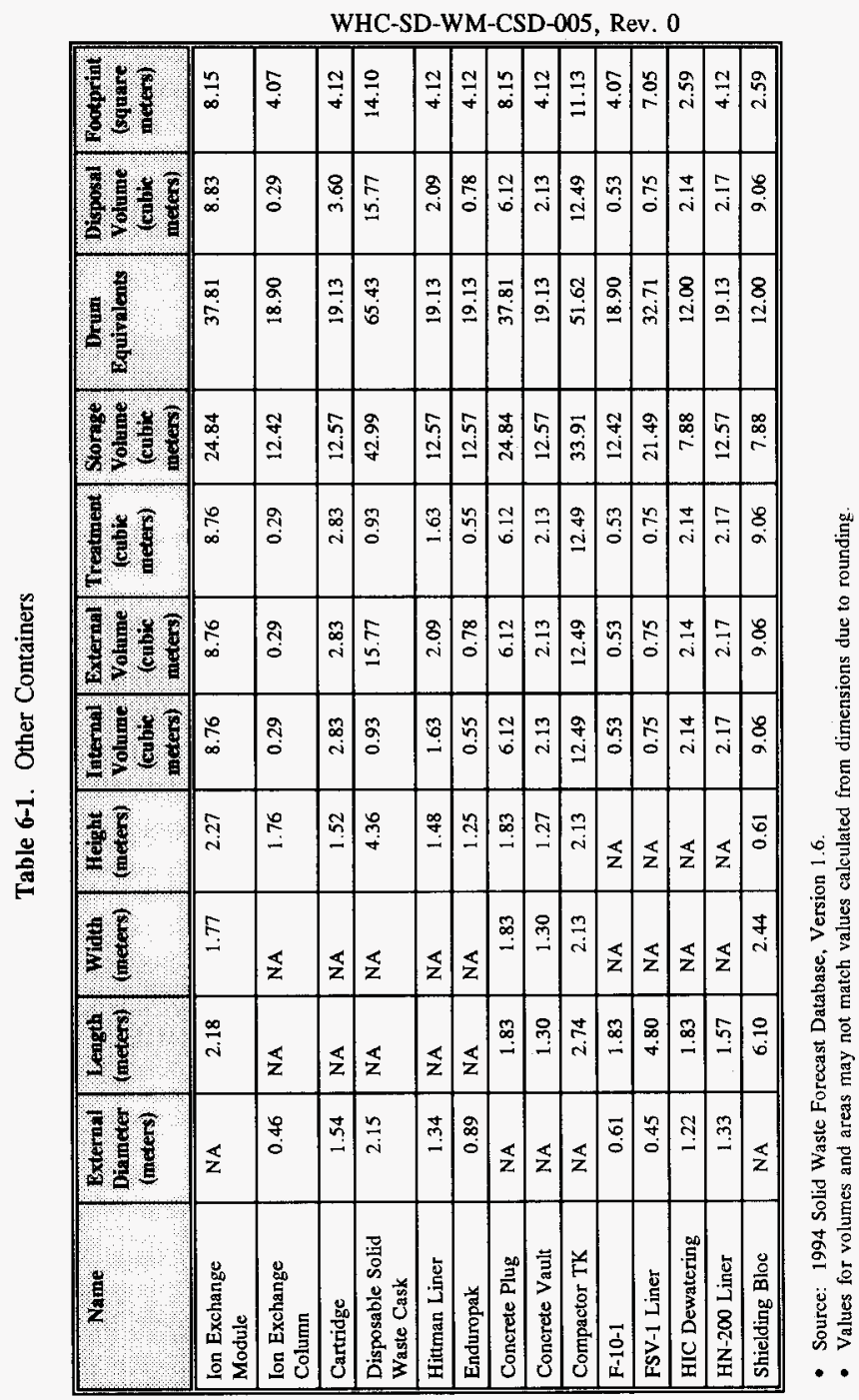




\section{WHC-SD-WM-CSD-005, Rev. 0}

\subsection{References}

Burgess, J. S. WHC-SD-TP-PDC-020 Rev-2, Packaging Design Criteria, Transfer and Disposal of Long Length Equipment, Hanford Tank Farm Complex.

Romano, T. September 1993, WHC-SP-1070, Radioactive Hazardous Waste Materials Packaging Directory.

ANSI MH2-1991, for Material Handling (Containers) Steel Drums and Pails.

1994 Solid Waste Forecast Database, Version 1.6.

Solid Waste Information Tracking System. 
WHC-SD-WM-CSD-005, Rev. 0

Intentionally Left Blank 
WHC-SD-WM-CSD-005, Rev. 0

Page 1 of 1

DISTRIBUTION LIST

Westinghouse Hanford Company

R. R. Ames

T4-03

R. A. Barcot

V. L. Bl anchard

R. J. Bottenus

F. M. Coony

P. J. Crane

R. J. Giroir

C. K. Girres

C. V. Hawkes

K. L. Hladek

R. M. Irwin

W. S. Josephson

M. R. Kerns

R. S. Lipinski

S. L. Metzger

D. E. Nester

T. K. Orgill

R. D. Pierce

B. G. Place

J. P. Sederburg

D. J. Sommer

G. C. Triner

0 . J. Valero (5 copies)

13-01

T3-04

T4-02

T3-01

T4-03

T4-05

T3-28

13-05

T3-01

T4-03

T3-04

T3-01

T3-04

T4-51

T3-01

T4-51

T3-04

T3-01

T3-01

T6-33

T3-05

T3-01

T3-04

M. S wright

T3-28

Pacific Northwest National Laboratory
T. J. Deforest (5 copies)
K7-97
D. B. Elliot
$\mathrm{K} 8-17$
R. A. Fowler
$\mathrm{K} 8-11$
H. S. Konynenbelt
K7-97
J. Morgan
K7-97
W. A. Ross
K7-94
R. W. Schultz
K8-17
K. J. Tempelton (5 copies)
K7-94 